EPJ Web of Conferences 34, 01004 (2012)

DOI: $10.1051 /$ epjconf/20123401004

(C) Owned by the authors, published by EDP Sciences, 2012

\title{
In search of science, in search of meaning
}

\author{
Philippe Deterre ${ }^{1, \mathrm{a}}$
}

Laboratoire Immunité et Infection, UMR-S 945 INSERM-UPMC, Faculté de Médecine Pitié-Salpêtrière, Paris, France

\begin{abstract}
Just before passing Pierre Valiron made the last corrections of a manuscript for a book called Chercheurs en science, Chercheurs de sens (Editions de l'Atelier, Paris, 2009). I coauthored this book with him.
\end{abstract}

Just before passing Pierre Valiron made the last corrections of a manuscript for a book called Chercheurs en science, Chercheurs de sens (Editions de l'Atelier, Paris, 2009). I coauthored this book with him. The book was initiated by the proposal of a French editor to write a book consisting of a dialogue between two researchers, one a Christian believer and the other a non Christian and/or non believer. Pierre and I are both scientific researchers appointed by the French National Center of Scientific Research (CNRS): while Pierre was an astrophysicist, I am a biologist. Pierre was agnostic, while I am a Christian believer and a catholic priest. Pierre was very enthusiastic to initiate and to do that job together. The book consists of a dialogue about our passion for scientific research, about problems encountered nowadays by people doing that job, and about the essential task to communicate science with large public audiences. So, our dialogue is also largely devoted to the way that researchers may approach the religions, Bible and Christian belief. We decided very early that our potential book would have at least three aspects:

- Sciences from the researcher point of view: astrophysics and cellular biology

- Confrontation about religions and Bible, especially on creationism

- Dialogue about the relationship between research and society

Our dialogue occured during the period of vivid contestations by researchers, in 2004-2005. The first version of our manuscript was done right at the moment of the final event called "Etats Généraux de la Recherche" organized by the researchers association "Sauvons la Recherche" . After some trials and tribulations, the editor evaluated positively the content of our manuscript, but not its form. So the editor proposed to us a re-writing by Christophe Henning, who did the job very well. The book contents of 6 chapters (i) Researchers in research; (ii) Which research engine? (iii) Creation and creationism; (iv) Science and faith: a matter of language; (v) A world of question; (vi) The commitment of the researchers.

Pierre Lena, a well known French astrophysicist and member of the French Scientific Academy, consented to write the foreword. According to him, "the book testifies of a research of coherence, integrating even the human fate, whether claiming God or denying Him”. He added an alarming question we also addressed: "Thanks to science and research, our knowledge has become huge, as much as the power it gave to us. Do we remain reasonable enough, placing human value above all?"

According to me, our book addresses besides three interesting points:

- The importance of working in basic research, that is very different than that of an engineer. This distinction is important in France where most of the best students are in engineer schools.

a e-mail: philippe.deterre@upmc.fr

${ }^{1} \mathrm{http}: / / \mathrm{www}$. sauvonslarecherche.fr/ 
- However, both of our approaches to this job are relatively different: Pierre, the physicist, is very receptive to the beauty of nature and of the simplicity of its laws. As a biologist in front of the complexity of the living, I am more sensitive to the provisional character of our models. We are very often forced to change our point of view, and our models of explanation.

- As an unbeliever, Pierre asked me to account for the existence and the essence of God. To his point of view, I should believe, as for instance Descartes did, to the existence of a sort of artisan or journeyman who made the universe at the very beginning. I often answered to Pierre that this is not my own conception of God: "He" is not a craftsman who finely tunes the laws of nature. It is a presence, a kind of word, who is close to the mankind.

Our book contains some reference to great researchers like Francois Jacob. The book ends with a mention of Thomas Henry Huxley in a conference called "Evolution and Ethics" more than a century ago: "the ethical progress of society depends, not on imitating the cosmic process, still less in running away from it, but in combating it". I find it very relevant for a meeting of astrophysicists, in this Memorial Day for our colleague and friend. 